\title{
HISTORIA HISTORIOGRAFII - DROGA DO METAREFLEKSJI HISTORYCZNE]
}

Wiktor WERNER

Uniwersytet im. Adama Mickiewicza

1) Jakie Pan/Pani przyznaje miejsce historiografii w dziedzinie nauk historycznych? W szczególności chcielibyśmy zapytać o relację utrzymywaną przez historię historiografii z historiografią, w tym z historiograficą idei, z jednej strony, i metodologią historii, z drugiej. Na czym polega specyficzna tożsamość historii historiografii jako odrębnej dyscypliny badawczej w dziedzinie nauk historycznych?

Historię historiografii samą w sobie można uznać za bardzo zróżnicowaną wewnętrznie dziedzinę nauk historycznych.

HH może być pojmowana (ujęcie I) jako generalne badanie dziejów badawczej i publikacyjnej aktywności historyków oraz instytucji tworzących i upowszechniających wiedzę historyczną (w ramach historii powszechnej lub historii narodowych). Jako taka będzie zajmować się zabezpieczaniem oraz badaniem źródeł wytwarzanych w ramach wspomnianych aktywności. Historyk historiografii w ujęciu I będzie studiował biografie historyków opierając się na źródłach archiwalnych, prywatnych (korespondencji, pamiętnikach etc.) oraz dzieje instytucji takich jak uczelnie, archiwa, instytuty i towarzystwa naukowe, muzea itp. wykorzystując wszelkie dostępne źródła. Zasadniczy efekt aktywności historyków czyli narracja historyczna będzie tutaj jednym z wielu dostępnych badaniu o interpretacji źródeł zasadniczo nieuprzywilejowanym.

Historia historiografii może być także pojmowana i praktykowana w sposób, który lączy ją silniej z historią nauki (ujęcie II). Wówczas wzrasta znaczenie narracji historycznej (publikacji historycznych) jako źródła. Obraz przeszłości wypracowywany w badaniach historycznych staje się punktem dojścia badań HH. Historyk historiografii analizuje proces badawczy i publikacyjny nie jako autonomiczne 
wydarzenia, lecz w celu ukazania kontekstu dla obrazu dziejów będącego efektem tych procesów. HH jako dziedzina historii nauki ukazuje tu przemiany dokonujące się $\mathrm{w}$ ramach nauk historycznych badając równolegle przemiany w historycznych obrazach świata jak i w kontekście jego powstawania (czyli w procesie osobowego oraz instytucjonalnego tworzenia wiedzy historycznej, który jest głównym celem ujęcia I).

Historia historiografii jest również wiązana z metodologią historii i teorią wiedzy historycznej (ujęcie III). Wówczas perspektywa badawcza skupiona jest na analizie historycznego obrazu świata będącego efektem badań historycznych. Historyk historiografii zadaje sobie pytania dotyczące tego jakie założenia wstępne, wybrane metody badawcze oraz wybory repozytoriów źródłowych wywarly wplyw na powstanie takiego a nie innego obrazu rzeczywistości historycznej? Wiedza źródłowa dotycząca osób oraz instytucji zaangażowanych w badania historyczne jest tutaj ważna, lecz ewidentnie służebna względem głównego celu badawczego jakim jest ukazania uwarunkowań konkretnego historycznego obrazu świata. Nierzadko w tym ujęciu zestawia się różne obrazy świata, które powstały w oparciu o badania tych samych źródeł, lecz z zastosowaniem innych założeń wstępnych lub metod badawczych. HH praktykowana w myśl ujęcia III ma generalnie porównawczy charakter a podstawowym jej celem jest formułowanie ogólnych twierdzeń (teoretycznych) dotyczących mechanizmów powstawania i funkcjonowania wiedzy historycznej.

Nieco inny charakter ma HH, jeżeli powiąże się ją z historią idei i/lub historią intelektualną (ujęcie IV). Wówczas podstawowym przedmiotem zainteresowania są relacje zachodzące między wiedzą historyczną a jej (aktualnym) otoczeniem kulturowo-społecznym. Historyk historiografii bada tutaj recepcję twierdzeń historycznych i ich wpływ na sytuację społeczną oraz kulturową czasów, w których te twierdzenia byly formulowane i czasów, w których byly odczytywane. Taka perspektywa badawcza poszerza drastycznie zakres adekwatnych źródeł co zmusza historyka do dokonywania ich selekcji lub zachęca do tworzenia interdyscyplinarnych zespołów badawczych (historyk historiografii + literaturoznawca + socjolog + ekonomista itp.) Zasadniczym celem badań wydaje się być w przypadku ujęcia IV ukazanie procesu przeplywu wiedzy historycznej do społecznego otoczenia oraz wskazanie/udowodnienie, że nastąpił wplyw tej wiedzy na procesy/zjawiska kulturowe.

2) Czy mógłby/mogłaby Pan/Pani wskazać na 5-10 współczesnych prac z zakresu historii historiografii opublikowanych w językach kongresowych w ciąqu ostatnich dziesięciu lat, które mogłyby/powinny zostać włączone do kanonu lektur historyka historiografii w naszym kraju? W naszej intencji lista taka mogłaby również być 
pomocna w formułowaniu planów wydawniczych dotyczących translacji dzieł z zakresu historii historiografii na język polski.

- BentleyMichael, Companion to Historiography, Routledge, 2006

- Day Ronald E, The Modern Invention of Information: Discourse, History, and Power, SIU Press, 2008

- Durepos Gabrielle, Mills Albert J., Anti-history: Theorizing the Past, History, and Historiography in Management and Organization Studies, IAP 2012

- Mahoney MS Haigh T., Histories of computing, Harvard University Press 2011

- Söderquist Thomas, The Historiography of Contemporary Science and Technology, Routledge 2013

- Tonkin Elizabeth, McDonald Maryon, Chapman Malcolm K. (eds.), History and Ethnicity, Routledge 2016

- Tucker Aviezer (ed.), A Companion to the Philosophy of History and Historiography, John Wiley \& Sons, 2011

- Zhmud L., The Origin of the History of Science in Classical Antiquity, Berlin 2006

3) Jaki rodzaj napięcia dostrzega Pan/Pani między, jak się wydaje, nieredukowalnymi roszczeniami historii historiografii do (a) spełniania kryteriów naukowego dyskursu historiograficznego i (b) objęcia uwagą badawczą całości historii gatunku historiograficznego, od jego pierwszych form w starożytności, poprzez kolejne epoki, po współczesność? W jaki sposób można dzisiaj połączyć teoretycznie, a także praktycznie, naukowość historii historiografii z jej polihistorycznością?

Historia historiografii jest dziedziną, która łączy nie tylko różne repozytoria źródłowe, lecz także różne perspektywy badawcze (por. pyt. 1). W zależności od dominującej w danym przedsięwzięciu badawczym perspektywy możliwa jest realizacja różniących się nieco od siebie kryteriów naukowości zdefiniowanych dla różnych specjalizacji historycznych. Dla historii historiografii najsilniej związanej z faktograficzną historiografią (ujęcie I) najistotniejszym kryterium jest poprawna krytyka źródel pozostałych po procesie badawczym. Dla HH orientującej się w stronę historii nauki (ujęcie II) równie ważna jest orientacja badacza (często zdobywana również na podstawie literatury przedmiotu) w przemianach jakie dokonują się w modelu badań historycznych. W odniesieniu do HH powiązanej z metodologią historii (ujęcie III) kryterium naukowości refleksji wiąże się ze zdolnością do konceptualnego wyłonienia z badania narracji historycznej zależności między wdrożoną metodą/przyjętymi 
założeniami a uzyskanymi efektami - co wymaga orientacji w zagadnieniach epistemologii historii i teorii wiedzy historycznej. W odniesieniu do $\mathrm{HH}$ związanej z historią idei/historią intelektualną (ujęcie IV) istotnym kryterium naukowości refleksji jest sprawność w uchwyceniu problemu recepcji/wplywu społecznego narracji historycznej co wymaga znajomości metod ilościowej lub/i jakościowej interpretacji zjawisk społecznych/kulturowych.

4) Prosimy o wskazanie od jednej do trzech postaci lub ich dzieł z przeszłości polskiej historii historiografii, której/których dorobek dzisidj niesłusznie pozostaje w cieniu, a zasłuquje na aktualizujące przypomnienie przez samoświadomość historiografii. Prosimy o podanie uzasadnienia wyboru. Jaka przeoczona lekcja z przeszłości naszej dyscypliny mogłaby zostać dzisiaj przyswojona?

Wskazane byłoby ponowne przeczytanie prac autorów już znanych, lecz nie kojarzonych $\mathrm{z}$ historią historiografii na skutek wąskiego definiowania zarówno pojęcia „historiografia” jak i „historia historiografii”. Autorzy których mam tu na myśli to: Leszek Kołakowski (w szczególności: „Główne nurty marksizmu”) i Barbara Skarga (w szczególności jej praca: „Granice historyczności”).

Uzasadnieniem jest potrzeba otwarcia się historii historiografii na szerszą perspektywę kulturową i korzyści jakie mogą wynikać z przyswojenia pojęć oraz instrumentów historii filozofii. Pozwoli to na wzbogacenie historii historiografii praktykowanej w ujęciu (III-IV-por. pyt. 1.).

5) Prosimy o zaproponowanie nowego kanonu lektur z zakresu polskiej historii historiografii zawierającego do 10 pozycji bibliograficznych. Chodzi nam o listę niewątpliwie wybitnych bądź cieszących się uznaniem dzieł polskich historyków historiografii z ostatnich dwóch stuleci i współczesnych, wyselekcjonowaną (w akcie wyobraźni) w ten sposób, że gdyby lista ta (zbiór dzieł) stała się realnym kanonem kształtującym tożsamość historii historiografii w Polsce i zastąpiła, choćby po części, kanon obecnie realny, pozwoliłaby na ukierunkowanie badań poza dzisiejsze horyzonty naszej dyscypliny. Prosimy o wyobrażenie sobie przyszłości dyscypliny poprzez wyselekcjonowanie innego, niż zwykle wyobrażane, obrazu jej przeszłości. 
Nie w pełni zgadzam się z założeniami pytania, gdyż nie uważam powszechnie obecnego kanonu (tzn. najczęściej powtarzających się w sylabusach z HH) lektur za wymagającego radykalnej przebudowy. Wiele z omawianych obecnie tytułów takich jak prace J. Topolskiego, A. F. Grabskiego, W. Wrzoska są jak najbardziej wartościowe i godne omawiania. Dlatego zgadzając się z pomysłem „myślowego eksperymentu” chciałbym zaznaczyć, że sformułowany zostanie tutaj nie tyle „nowy, lepszy kanon” co kanon alternatywny wskazujący na te aspekty historii historiografii (obrazujące żywy związek historiografii z innymi społecznymi i humanistycznymi dziedzinami wiedzy), które obecnie są prawie całkowicie pomijane a być może należy im się również nieco miejsca w wykładzie naszej dziedziny wiedzy.

- L. Kołakowski, Główne nurty marksizmu, t. 1-3, PWN 2009

- B. Skarga, Granice historyczności, PiW 1989

- J. Szacki, Historia myśli socjologicznej. Wydanie nowe. PWN 2002

- M. Janion, M. Żmigrodzka, Romantyzm i historia, Gdańsk 2001

- J. Topolski, Świat bez historii, Poznań 2007

- W. Tatarkiewicz, Historia filozofii, PWN 2003

6) Jakie zadania dydaktyczne stoją przed uniwersyteckim kursem z zakresu historii historiografii? Jakie jest miejsce historii historiografii w kształceniu historyka ordz w nabywaniu ogólnego wykształcenia humanistycznego?

Odpowiedź na to pytanie nie może być jednoznaczna gdyż zależy od tego jak zdefiniujemy cele związane $\mathrm{z}$ akademickim kształceniem historyka i towarzyszące temu procesowi wartości. Jeżeli przyjmiemy, że zależy nam na utrzymaniu jakości edukacji historycznej oraz chcemy aby absolwenci historii świadczyli o jej wartości to zajęcia $\mathrm{z}$ historii historiografii powinny rozwijać zarówno wiedzę jak i umiejętności. Jest to możliwe w sytuacji, w której zajęcia te będą okazją do ukazania bogactwa i złożoności metod badawczych stosowanych w naukach historycznych oraz głębokiego zakorzenienia wiedzy historycznej w kulturze i społeczeństwie. $Z$ perspektywy tych celów i wartości przydatne jest prezentowanie historii historiografii w ujęciach II-IV (por. pyt. 1). 